\title{
Bioluminescence immunoassay for neurotransmitter, serotonin using aequorin as a Label
}

\author{
Jieun Ryu, Hee Seon Choi, Hoyoung Park and Insook Rhee Paeng ${ }^{\star}$ \\ Department of Chemistry, Seoul Women's University, Seoul 139-774, Korea \\ (Received December 22, 2009; Accepted January 21, 2009)
}

\section{Aequorin을 표지물질로 사용한 신경전달물질, 세로토닌에 대한 생물발광면역분석법

\author{
류지은 · 최희선 · 박호영 · 이인숙` \\ 서울여자대학교 화학과
} \\ (2009. 12. 22. 접수, 2009. 1. 21. 승인)}

\begin{abstract}
A sensitive competitive heterogeneous bioluminescence immunoassay for serotonin was developed using photoprotein, aequorin as a label for the first time with the optimal assay conditions; especially, serotoninavidin conjugate was prepared by Mannich reaction and the synthetic process of serotonin-avidin conjugate was optimized by controlling the initial molar ratios of serotonin, formaldehyde and avidin $(1: 12,000: 25)$. The developed bioluminescence immunoassay for serotonin showed good sensitivity (LOD of $0.68 \mathrm{ng} / \mathrm{mL}$ ) with wide area of dynamic range $\left(5.0 \times 10^{-10} \mathrm{M} \sim 5.0 \times 10^{-7} \mathrm{M}\right.$ ). (cf. the range for serotonin in human blood serum is $151 \pm 45 \mathrm{ng} / \mathrm{mL}$ ). In addition, cross-reactivity studies demonstrated that 5-methoxytryptamine showed some cross-reactivity (28.0\%), whereas 3-methylindole, melatonin and 5-hydroxylindole-3-acetic acid showed no crossreactivity, and good recoveries were obtained in serum. Thus, this developed method provides a good tool to monitor serotonin in serum.
\end{abstract}

요 약: 본 연구는 생물발광단백질인 aequorin을 표지물질로 사용해 신경전달물질인 serotonin에 대한 생물 발광면역분석법을 처음으로 개발하였다: serotonin-avidin 접합체는 Mannich 법으로 합성하였으며, 최적화 된 avidin: formaldehyde: serotonin의 초기 몰 비는 $1: 12,000: 25$ 이었다. 개발된 serotonin에 대한 생물발광면 역분석법은 좋은 감도 $(\mathrm{LOD}$ of $0.68 \mathrm{ng} / \mathrm{mL})$ 와 넓은 검출 범위 $\left(5.0 \times 10^{-10} \mathrm{M} \sim 5.0 \times 10^{-7} \mathrm{M}\right)$ 를 나타내 었다(참고, 혈청 내 serotonin의 양은 $151 \pm 45 \mathrm{ng} / \mathrm{mL}$ 이다.). 교차반응성에 대한 연구 결과, 5 -methoxytryptamine 은 $28.0 \%$ 의 교차반응성을 보인 반면, 3-methylindole, melatonin 그리고 5-hydroxylindole-3-acetic acid 은 교 차반응성을 보이지 않았다. 또한, 혈청에서의 회수율은 만족할만한 값이 얻어졌다. 그러므로, 본 연구에서 제안된 생물발광면역분석법은 혈청 내의 serotonin 을 모니터링 하는데 좋은 분석법으로 사용될 수 있다.

Key words: Bioluminescence immunoassay, Aequorin, Neurotransmitter, Serotonin

Corresponding author

Phone : +82-(0)2-970-5657 Fax : +82-(0)2-970-5972

E-mail : irpaeng@swu.ac.kr 


\section{Introduction}

Immunoassay has extensively been proven to be the method of choice in many clinical applications, due to their simplicity, specificity, and extremely low detection limits. ${ }^{1-3}$ For the sensitive immunoassay development, the choice of an appropriate signal generator is very essential. Thus, a variety of labels have been used in the development of immunoassays including radioisotopes, enzymes, and bioluminescent, chemiluminescent, and fluorescent compounds, etc. Luminescence derived from a biological reaction at ordinary temperature is called as bioluminescence. In contrast to fluorescent and phosphorescent molecules, bioluminescent proteins generate the emission of light on the return to the ground state from an electronically excited species which is produced by a biological reaction. It is not associated with any generation of heat, called as "cold light". As a signal generator, bioluminescent reporter proteins have been used as an excellent label, which have advantages of low background, large dynamic range, high sensitivity, and no need of substrate or enhancer in immunoassay systems. ${ }^{4-6}$

Here, we used a photoprotein, aequorin as a label which is a calcium-activated photoprotein. ${ }^{7-10}$ Upon binding $\mathrm{Ca}^{2+}$ ions, the aequorin undergoes a conformational change, leading to oxidation of coelenterazine to coelentimide. The reaction is a single turnover event and yields emission of a flash of light at $\lambda_{\max }$ $(469 \mathrm{~nm}){ }^{11}$

Serotonin was selected as a model compound for this study, which is well known to act as a neurotransmitter in the control and regulation of various brain functions, and has been strongly implicated in several pathological conditions such as essential hypertension. ${ }^{12-14}$ Abnormal concentrations of serotonin in plasma have been shown to reflect the serotonergic function in the central nervous system. Therefore it is very important to monitor the serotonin level in plasma.

In this work, we developed a sensitive competitive heterogeneous bioluminescence immunoassay for serotonin using a photoprotein, aequorin as a label.
Avidin/biotin mediated assay was also performed for signal amplification and activity conservation of aequorin. A signal-generator should retain a useful residual activity, thus various biotin-aequorin conjugates were prepared. And serotonin-avidin conjugate was also prepared. From these, serotonin assay was optimized and their dose-response behaviors were examined. In order to evaluate this assay, serum matrix analysis with spiked serotonin was performed, and structurally similar molecules were employed to determine the specificity of this assay.

\section{Experimental}

\subsection{Reagents}

Serotonin hydrochloride, 3-methylindole, 5-methoxytryptamine, 5-hydroxyindole-3-acetic acid, serotonin creatine sulfate and anti-serotonin antibody developed in rabbit (S5545) were purchased form Sigma (St. Louis, MO, USA). N-acetyl-5-methoxytryptamine (melatonin) was obtained from Fluka (Ronkonkoma, NY, USA). Aequorin from jellyfish type III, bovine serum albumin (BSA), tris(hydroxymethyl)aminomethane (Tris) free base, avidin from egg white, Tween $20^{\circledR}$, N-hydroxysuccinimido biotin (NHS-biotin), ethylenediaminetetraacetic acid disodium salt (EDTA-2Na) were purchased from Sigma. Sodium bicarbonate, sodium carbonate, sodium phosphate monobasic, sodium phosphate dibasic and sodium chloride were purchased from Duksan Pure Chemical (Ansan, Kyonggido, Korea). All chemicals were of analyticalreagent grade or better. All solutions were prepared using triply deionized distilled water (Milli-Q water purification system, Millipore, Billerica, MA, USA).

\subsection{Instrumentations}

Bioluminescence light intensity was measured using MLX-microtiter plate luminometer (Dynex Co., Chantilly, VA, USA) using a $100 \mu \mathrm{L}$ fixed volume injector. BLIA was performed in a low-binding microlite-1 plate (Dynex technologies Inc., USA), neutravidin-coated white polystyrene flat-bottomed microtiter plates (Pierce, Rockford, IL, USA) and Maxisorp $^{\mathrm{TM}}$ flat well geometry white color plate 
(Nunc), and washed using Multiwasher III (Tricontinent, Grass valley, CA, USA). The $\mathrm{pH}$ values were measured with an Orion $\mathrm{pH}$ meter (Thermo electron Corporation, Beverly, MA, USA).

\subsection{Preparation of conjugates}

Serotonin-avidin conjugates were prepared according to Mannich reaction. The required amount of formaldehyde dissolved in anhydrous DMF was added to coupling buffer ( $650 \mathrm{mM}$ sodium acetate, $\mathrm{pH}$ 6.0) containing given amounts of serotonin creatine sulfate and avidin. Initial molar ratio of serotoninavidin conjugate was controlled by initial molar ratio of three components; serotonin, formaldehyde and avidin. Several initial molar ratios of serotonin were applied with fixed amount of formaldehyde and avidin (serotonin:formaldehyde:avidin=x:12,000:1, $\mathrm{x}=0 \sim 100$ ). And then the initial molar ratio of formaldehyde was studied with fixed amount of serotonin and avidin (serotonin: formaldehyde:avidin $=25: \mathrm{y}: 1, \mathrm{y}=300$ 24,000). The reaction was run for $2 \mathrm{~h}$ at RT under stirring. And then, the reaction mixture was dialyzed (30 mM phosphate, $\mathrm{pH} 7.4$ ) and diluted to a final concentration of $7.6 \times 10^{-6} \mathrm{M}$ avidin (stock solution of conjugate).

Aequorin-biotin conjugates were made by reacting aequorin with different amounts of NHS-biotin. The required amount of NHS-biotin dissolved in anhydrous DMF was added to coupling buffer ( $50 \mathrm{mM}$ sodium bicarbonate, $\mathrm{pH} 8.5$ containing $4 \mathrm{mM}$ EDTA) containing a given amount of aequorin. The reaction mixture was stirred for $24 \mathrm{~h}$ at $4{ }^{\circ} \mathrm{C}$ and was dialyzed against $30 \mathrm{mM}$ Tris-HCl, $\mathrm{pH} 7.4$ containing $4 \mathrm{mM}$ EDTA, in order to remove the excess NHS-biotin and change the buffer from bicarbonate to Tris-HCl. And then it was diluted to a final concentration of $2.0 \times 10^{-7} \mathrm{M}$ aequorin (stock solution of conjugate). All conjugates were kept at $4{ }^{\circ} \mathrm{C}$.

\subsection{Optimization of assay conditions}

An anti-serotonin antibody of different concentrations $(0 \sim 290 \mu \mathrm{g} / \mathrm{mL})$ was prepared in the coating buffer (50 $\mathrm{mM}$ bicarbonate buffer, $\mathrm{pH} 9.5)$ and each solution $(100 \mu \mathrm{L})$ was immobilized on a Maxisorp ${ }^{\mathrm{TM}}$ plate with constant shaking ( $\sim 150 \mathrm{rpm})$ for overnight at $4{ }^{\circ} \mathrm{C}$. The plate was then washed 2 times with wash buffer, PBS-BT (30 mM PBS containing 0.1\% BSA and $0.05 \%$ Tween 20, pH 7.4).

Incubation time periods of each step were varied and investigated.

\subsection{Dose-response curves for serotonin}

Serotonin standard solution was prepared in assay buffer, PBS-B (30 mM PBS containing 0.1\% BSA, $\mathrm{pH} 7.4)$ as ranging in concentration from $5.0 \times 10^{-14}$ $\mathrm{M}$ to $5.0 \times 10^{-3} \mathrm{M}$. Each serotonin solution $(100 \mu \mathrm{L})$ was incubated with anti-serotonin antibody $(58 \mu \mathrm{g} /$ $\mathrm{mL}$ ) immobilized on Maxisorp ${ }^{\mathrm{TM}}$ plate, for $30 \mathrm{~min}$. at RT. And $100 \mu \mathrm{L}$ of $2.0 \times 10^{-6} \mathrm{M}$ serotonin-avidin conjugate (initial molar ratio of serotonin : formaldehyde : avidin=25:12,000:1) was added and allowed to incubate for an additional $1 \mathrm{~h}$ at RT. The plate was then washed twice with wash buffer, TBS-BET (30 $\mathrm{mM}$ TBS containing $0.1 \%$ BSA, 4 mM EDTA and $0.05 \%$ Tween 20, pH 7.4). A $100 \mu \mathrm{L}$ of $3.0 \times 10^{-8} \mathrm{M}$ biotin-aequorin conjugate solution in assay buffer, TBS-BE (30 mM TBS containing $0.1 \%$ BSA and 4 mM EDTA, $\mathrm{pH}$ 7.4), was added to the plate and it was incubated for an additional $30 \mathrm{~min}$. at RT and followed by wash. The contents of wells were mixed and positioned in the MLX luminometer. The bioluminescence light was measured after injection of $100 \mu \mathrm{L}$ of bioluminescence-triggering solution (100 $\mathrm{mM} \mathrm{CaCl}_{2}$ in $100 \mathrm{mM}$ Tris-HCl, $\mathrm{pH}$ 7.5). The emission signal in each well was collected at $0.1 \mathrm{~s}$ interval over a $3 \mathrm{~s}$ time period. All luminescence intensities reported are the average of at least triplicates and have been corrected from the contribution of the blank.

\subsection{Cross-reactivity study and matrix effect study}

A cross-reactivity study was performed in the same manner as the studies conducted for serotonin assay. The percent cross-reactivity was calculated using 3-methylindole, 5-methoxytryptamine, N-acetyl-5methoxytryptamine and 5-hydroxyindole-3-acetic acid which are structurally similar to serotonin. 
And matrix effect was also investigated for serotonin in serum. After dose-response curve in serum was obtained, the correlation diagram was constructed between absorbance in buffer and also in serum.

\section{Results and Discussion}

In heterogeneous assays, signal generator should retain a useful residual activity. ${ }^{15-18}$ Thus, various biotinaequorin conjugates were prepared by reacting aequorin with different amounts of NHS-biotin. The initial molar ratios of $0: 1,25: 1,50: 1$ and $100: 1$ of NHS-biotin : aequorin were examined and the residual activities of each conjugate were characterized to be $100,87,67$ and $0 \%$, respectively (\% residual activity was calculated as percentage of the activity of unconjugated aequorin being considered to be $100 \%$ ). In general, lower initial NHS-biotin : aequorin ratios used during the conjugation reaction yielded higher residual activity. Thus, we decided to use 50:1 conjugate based on good bioluminescence activity. Also, $3.0 \times 10^{-8} \mathrm{M}$ of the biotin-aequorin conjugate, 50:1 was selected from the calibration study for further studies. This reporter protein, aequorin showed a flash-type bioluminescence emission with more than $95 \%$ of the total light being emitted within $3 \mathrm{~s}$. Therefore, luminescence light intensity was collected over $3 \mathrm{~s}$ period of time in all subsequent experiments.

Serotonin-avidin conjugate was prepared by Mannich reaction which is the method for combining lysine $\left(-\mathrm{NH}_{2}\right)$ group of avidin to active hydrogen of indole in serotonin. The synthetic process of serotoninavidin conjugate was optimized by controlling the initial molar ratios of serotonin, formaldehyde and avidin. We repeated the experiments of varying the initial molar ratios of serotonin to avidin at fixed molar ratio of formaldehyde and avidin, and also varying the initial molar ratios of formaldehyde to avidin with fixed amounts of serotonin and avidin. The RLU signal reached the highest plateau as initial molar ratio of serotonin:avidin was more than 25: 1 , with formaldehyde:avidin (12,000:1) (Fig. 1(a)). We also obtained the maximum RLU signal at formaldehyde:avidin of 12,000:1 with serotonin:avidin (25:1) (Fig. 1(b)). Thus the initial molar ratio of serotonin: formaldehyde: avidin (25: 12,000:1) was chosen for serotonin-avidin conjugate preparation. In order to determine the amount of anti-serotonin antibody to be used in this experiment, a binder dilution study was performed and binder dilution curve was obtained by varying the amount of anti-serotonin antibody (Fig. 1(c)).

Experimentally, the sensitivity of this assay depends on two major variants. One is the antibody in
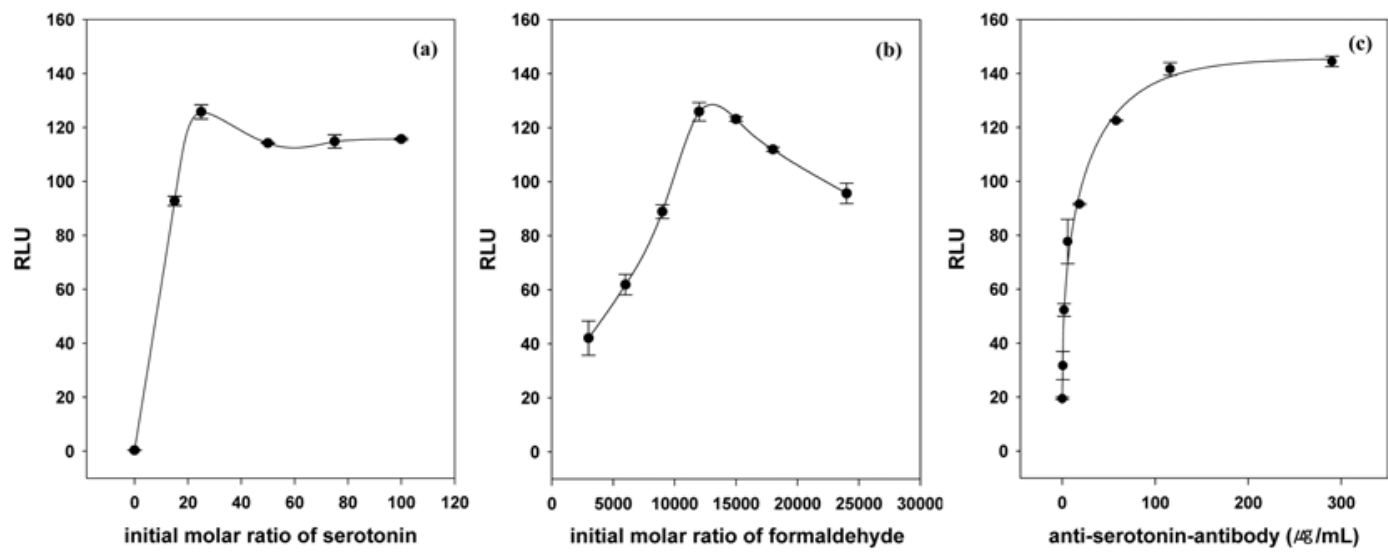

Fig. 1. (a) The effect of initial molar ratio of serotonin (serotonin:formaldehyde:avidin=x:12,000:1, $\mathrm{x}=0,15,25,50$ and 100), (b) The effect of initial molar ratio of formaldehyde (serotonin:formaldehyde:avidin= 25: y:1, y=3,000,6,000,9,000, 12,000, $15,000,18,000$ and 24,000), and (c) Binder dilution study of anti-serotonin antibody conducted using $7.6 \times 10^{-6} \mathrm{M}$ serotoninavidin conjugate and $3.0 \times 10^{-8} \mathrm{M}$ biotin-aequorin conjugate. Data points are the average plus \pm one standard deviation $(n=5)$. 

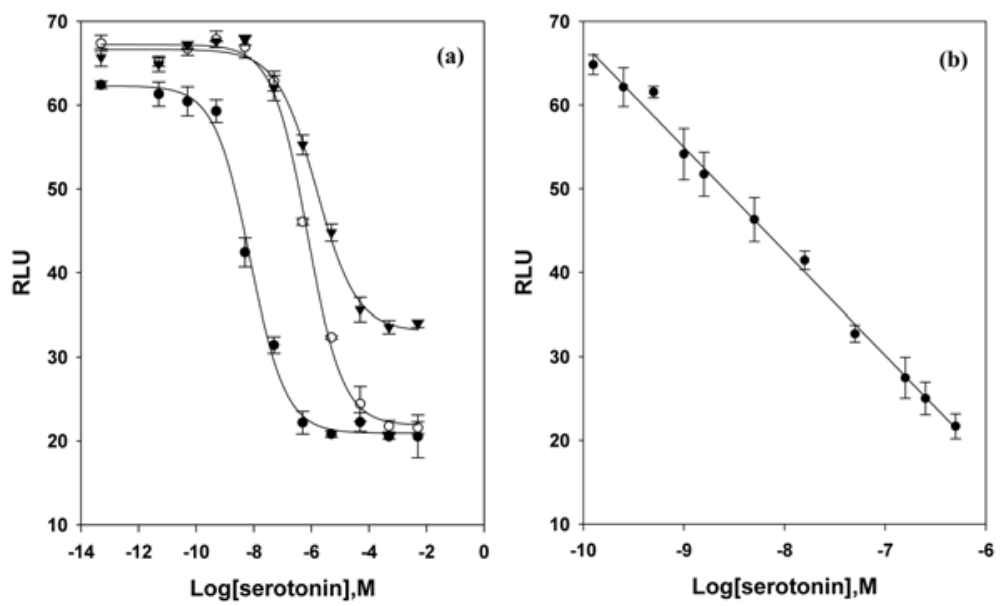

Fig. 2. (a) Dose-response curves for serotonin. The amounts of anti-serotonin antibody $(\mu \mathrm{g} / \mathrm{mL})$ and serotonin-avidin conjugate (M) were: $\mathrm{A}(\bullet) ; 58 \mu \mathrm{g} / \mathrm{mL}, 1.9 \times 10^{-6} \mathrm{M}, \mathrm{B}(\bigcirc) ; 5.8 \mu \mathrm{g} / \mathrm{mL}, 3.8 \times 10^{-6} \mathrm{M}$ and $\mathrm{C}(\boldsymbol{\nabla}) ; 0.58 \mu \mathrm{g} / \mathrm{mL}, 7.6 \times 10^{-6} \mathrm{M}$, respectively and (b) Calibration curve for serotonin. The condition is same as $\mathrm{A}(\mathbf{0})$ in (a), RLU $=-12.403 \times \log$ [serotonin, M] $-56.681\left(\mathrm{R}^{2}=0.994\right)$. Data points are the average plus \pm one standard deviation $(n=5)$.

concentration that is immobilized on the solid surface and the other is the competitor in concentration, serotonin-avidin conjugate, those are limited. A combination of both reagents was chosen based on dose-response curves obtained. Concentrations of competitor, serotonin-avidin conjugate $\left(1.9 \times 10^{-6}, 3.8\right.$ $\times 10^{-6}$ and $\left.7.6 \times 10^{-6} \mathrm{M}\right)$ and antibody (58, 5.8 and $0.58 \mu \mathrm{g} / \mathrm{mL}$ ) were controlled and dose-response curves were performed. Several dose-response curves were constructed using $3.0 \times 10^{-8} \mathrm{M}$ of biotin-aequorin conjugate according to a sequential mode in com- $^{-}$ petitive immunoassay. Fig. 2 (a) obtained by fixed amount of serotonin-avidin conjugate and antiserotonin antibody, respectively, with varying concentration of serotonin. Trace A in Fig. 2(a) was obtained with $58 \mu \mathrm{g} / \mathrm{mL}$ of anti-serotonin antibody and $1.9 \times 10^{-6} \mathrm{M}$ serotonin-avidin conjugate, trace $\mathrm{B}$ with $5.8 \mu \mathrm{g} / \mathrm{mL}$ and $3.8 \times 10^{-6} \mathrm{M}$, and trace $\mathrm{C}$ with $0.58 \mu \mathrm{g} / \mathrm{mL}$ and $7.6 \times 10^{-6} \mathrm{M}$. Among these three conditions examined, the resulting dose-response curves show that trace $\mathrm{A}$ has equal maximum RLU values with trace $B$ and $C$, but trace $A$ shows the lowest detection limit of $7.0 \times 10^{-10} \mathrm{M}$, which defined the concentration corresponding to 3 standard deviation above the mean from the blank. ${ }^{19}$ The dynamic range is from $5 \times 10^{-10}$ to $5 \times 10^{-7}$ M. Fig. 2(b) represents the calibration curve for serotonin; RLU $=-12.403 \times \log$ [serotonin, M]-56.681, $\left(\mathrm{R}^{2}=0.994\right)$. This indicates the possibility to application in vivo because the concentration range is included to range of serotonin $\left(8.5 \times 10^{-7} \mathrm{M}\right)$ in a blood serum.

In immunoassay, the ability of an antibody to yield a measurable response only for the target molecule describes as specificity. The specificity of the antibody was evaluated by cross-reactivity study using four structurally similar compounds, cross-reactants, such as 5-methoxytryptamine, 3-methylindole, melatonin and 5-hydroxylindole-3-acetic acid (Fig. 3) Crossreactivity studies were carried out by a competitive bioluminescence immunoassay by adding various free cross-reactants at different concentrations to compete with serotonin-avidin competitor, to bind with the antibody. Their $50 \% \mathrm{~B} / \mathrm{B}_{0}$ values were estimated and then their percent cross-reactivity was calculated: $\%$ cross-reactivity $=$ (concentration of serotonin giving $50 \% \mathrm{~B} / \mathrm{Bo}) /($ concentration of crossreactant giving $\left.50 \% \mathrm{~B} / \mathrm{B}_{0}\right) . \mathrm{B} / \mathrm{B}_{0}$ is the ratio of response $\mathrm{B}$, to the maximum response when no analyte is present $\mathrm{B}_{0}$. The $50 \% \mathrm{~B} / \mathrm{B}_{0}$ value and crossreactivity for each compound are given in Fig. 4. These results demonstrated that 5-methoxytryptamine showed some cross-reactivity (28.0\%), whereas 3-methylindole, melatonin and 5-hydroxylindole-3acetic acid showed no cross-reactivity. From those 
<smiles>O=C(O)Cc1c[nH]c2ccc(O)cc12</smiles>

3-Methylindole<smiles>COc1ccc2[nH]cc(CCNC(C)=O)c2c1</smiles>

Melatonin<smiles>COc1ccc2[nH]cc(CCN)c2c1</smiles>

5-Mehoxytryptamine<smiles>Cc1c[nH]c2ccccc12</smiles>

5-Hydroxyindole-3-acetic acid<smiles>NCCc1c[nH]c2ccc(O)cc12</smiles>

Serotonin

Fig. 3. Serotonin and its cross-reactants.

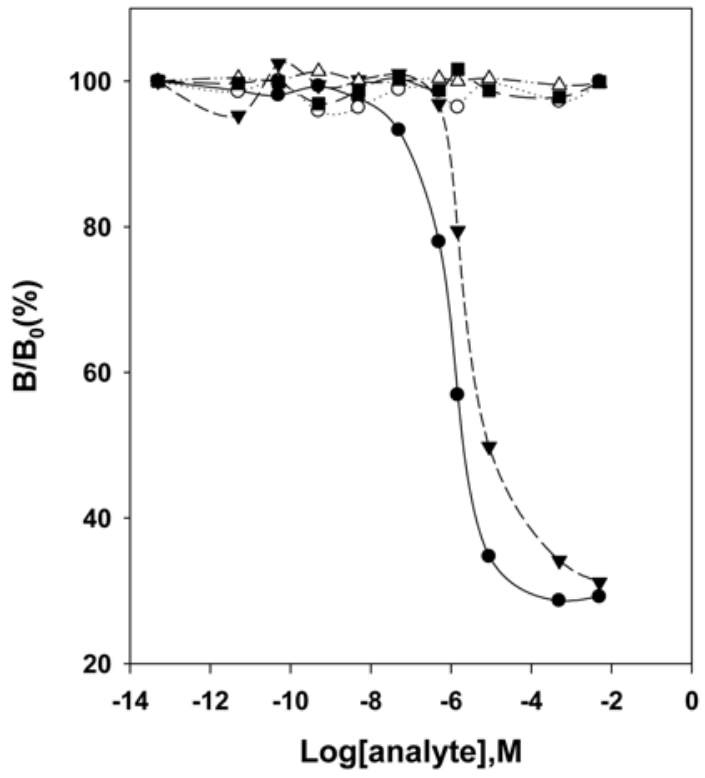

Fig. 4. Cross-reactivity study for cross-reactants: $\mathrm{A}(\boldsymbol{\bullet})$; serotonin, $\mathrm{B}(\bigcirc)$; 3-methylindole, $\mathrm{C}(\boldsymbol{\nabla})$; 5-methoxytryptamine and $\mathrm{D}(\triangle)$; melatonin and $\mathrm{E}(\boldsymbol{\square})$; 5hydroxyindole-3-aceticacid.

results, we can carefully conclude that 2-aminoethyl group at C-3 position of indole in serotonin is the

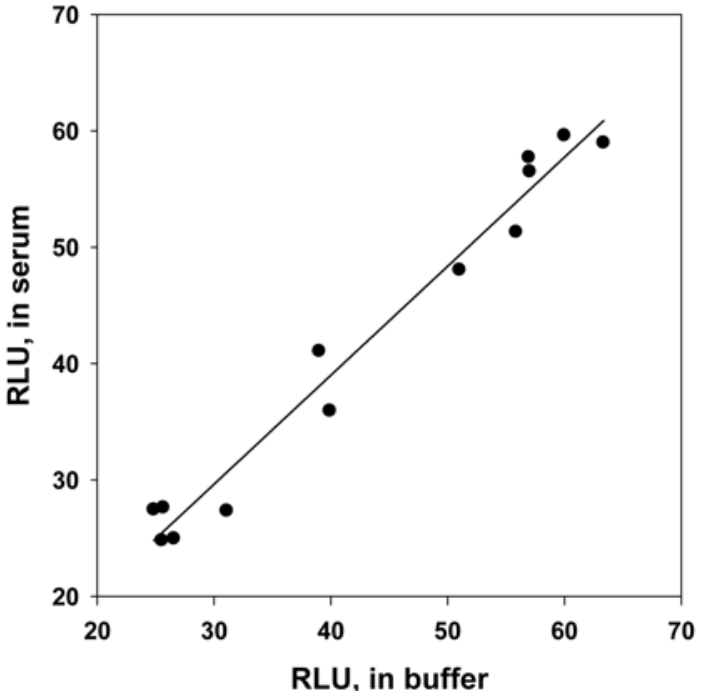

Fig. 5. The correlation diagram of the RLU obtained both in buffer and in serum: RLU (in serum) $=0.937 \times$ RLU (in buffer) $+1.534\left(\mathrm{R}^{2}=0.972\right)$.

main epitope for anti-serotonin antibody used in this work.

The dose-response curve in serum was also performed. A stock solution of serotonin standard was prepared in human serum (S7023) purchased 
Table 1. Recovery study

\begin{tabular}{ccc}
\hline \hline $\begin{array}{c}\text { Spiked conc. of serotonin } \\
(\mathrm{ng} / \mathrm{mL})\end{array}$ & $\begin{array}{c}\text { Recovery } \\
(\%)\end{array}$ & $\begin{array}{c} \pm \mathrm{SD} \\
(\mathrm{RSD}(\%))\end{array}$ \\
\hline 10 & 97.70 & $2.1(6.4)$ \\
1 & 92.14 & $1.8(4.3)$ \\
0.1 & 99.75 & $2.9(5.2)$ \\
\hline
\end{tabular}

from Sigma, and serially diluted. Even though this condition is not exactly same as the real patient samples, yet it can serve as a good model. Fig. 5 shows the correlation diagram of the RLU obtained both in buffer and in serum: RLU (in serum) $=0.937$ RLU (in buffer) $+1.534\left(\mathrm{R}^{2}=0.972\right)$. Free serotonin $(10,1$ and $0.1 \mathrm{ng} / \mathrm{mL})$ were spiked in serum, and percent recoveries were analyzed to $97.70 \%, 92.14 \%$ and $99.75 \%$, respectively. These works were done using 10 replicates and showed quite satisfactory results (Table 1).

\section{Conclusion}

A sensitive competitive heterogeneous bioluminescence immunoassay for serotonin was developed using a photoprotein, aequorin as a label for the first time with the optimal assay conditions; especially, serotonin-avidin conjugate was prepared by Mannich reaction and the synthetic process of serotoninavidin conjugate was optimized by controlling the initial molar ratios of serotonin, formaldehyde and avidin (1:12,000:25). The developed bioluminescence immunoassay for serotonin shows good sensitivity (LOD of $0.68 \mathrm{ng} / \mathrm{mL}$ ) with wide area of dynamic range $\left(5.0 \times 10^{-10} \mathrm{M} \sim 5.0 \times 10^{-7} \mathrm{M}\right)$. (cf. the range for serotonin in human blood serum is $151 \pm 45 \mathrm{ng} / \mathrm{mL}$ ). In addition, the average R.S.D. across all data points of the curve was less than $6 \%$ and good recoveries were obtained in serum. Thus, this developed method provides a good tool to monitor serotonin in serum. The analytical data for serotonin of our newly developed method were compared with those of other studies. Graves et al. ${ }^{20}$ determined of serotonin and its precursors in human plasma by capillary electrophoresis electrospray ionization time-of flight mass spectrometry, and obtained LOD of $26.0 \mathrm{ng} / \mathrm{mL}$.
Also, $\mathrm{Hu}$ and co-workers ${ }^{21}$ reported an electrochemical method with glassy carbon electrode casted with a film of carbon nanotube, and LOD of $0.88 \mathrm{ng} /$ $\mathrm{mL}$. Compared our results obtained in the work with those reported by others, our data were superior in terms of detection limit and dynamic range.

\section{Acknowledgement}

This work was supported by a special research grant from Seoul Women's University (2009).

\section{References}

1. R. F. Masseyeff, W. H. Albert and N. A. Staines, "Methods of Immunological Analysis" Vols. 1 and 2, N. A. Stanines, Ed., Wiley-VCH, NY, U.S.A., 1993.

2. E. P. Diamandis and T. K. Christopoulos, "Immunoassay", Academic Press, San Diego, U.S.A., 1996.

3. J. M. Kendall and M. N. Badminton, Trends Biotechnol., 16, 216-224(1998).

4. Y. N. Shim and I. R. Paeng, Anal. Sci., 17, a41 a44 (2001).

5. S. Shrestha, I. R. Paeng, S. K. Deo and S. Daunert, Bioconjugate Chem., 13, 269-275(2002).

6. Y. N. Shim and I. R. Paeng, Bull. Kor. Chem. Soc., 24, 70-74(2003).

7. C. H. George, J. M. Kendall, A. K. Campbell and W. H. Evans, J. Biol. Chem., 273, 29822-29829(1998).

8. S. Ramanathan, J. C. Lewis, M. S. Kindy and S. Daunert, Anal. Chim. Acta., 369, 181-188(1998)

9. C. L. Crofcheck, A. L. Grosvenor, K. W. Anderson, J. K. Lumpp, D. L. Scott and S. Daunert, Anal. Chem., 69, 4768-4772(1997).

10. B. Galvan and T. K. Christopoulos, Anal. Chem., 68, 3545-3550(1996).

11. D. Prasher, R. O. McCann and M. J. Cormier, Biochem. Biophys. Res. Commun., 126, 1259-1268(1985).

12. Y. Kumarasamy, M. Middleton, R. G. Reid, L. Nahar and S. D. Sarker, Fitoterapia, 74, 609-712(2003).

13. I. Semak, E. Korik, M. Naumova, J. Wortsman and A. Slominski, Arch. Biochem. Biophysics, 421, 61-66(2004).

14. M. Israel, Neurochem. International, 42, 215-220(2003).

15. J. Kim, M. Jeon, K.-J. Paeng and I. R. Paeng, Anal. Chim. 
Acta., 619, 87-93(2008).

16. M. Jeon and I. R. Paeng, Ana. Chim. Acta., 619, 180185(2008).

17. M. Jeon, J. Kim, K.-J. Paeng, S.-W. Park and I. R. Paeng, Microchem. J., 88, 26-31(2008).

18. J. Kim, H. Park, J. Ryu, O. Jeon and I. R. Paeng, J. Immunoassay and Immunochemistry 31, 33-44(2010).
19. R. Ekins and P. Edwards, Clin. Chem., 43, 1824-1837 (1997).

20. Z. D. Peterson, M. L. Lee and S. W. Graves, J. Chromatogr. B., 810, 101-110(2004).

21. K. Wu, J. Fei and S. Hu, Anal. Biochem., 318, 100106(2003). 